\title{
Bir Devlet Hastanesine Akut Gastroenterit ile Başvuran Hastalarda Rotavirüs ve Enterik Adenovirüs Enfeksiyonu Sıklığı
}

\author{
Frequency of Rotavirus and Enteric Adenovirus Infection in Patients Presenting \\ to a State Hospital with Acute Gastroenteritis
}

\section{Özlem Kirişci ${ }^{1}$, Gürkan Muratdağ ${ }^{2}$}

${ }^{1}$ Necip Fazıl Şehir Hastanesi, Tibbi Mikrobiyoloji Laboratuvarı, Kahramanmaraş

${ }^{2}$ Sakarya Üniversitesi Tip Fakültesi, Aile Hekimliği A.D, Sakarya

\author{
Yazışma Adresi / Correspondence: \\ Gürkan Muratdağı \\ SSakarya Üniversitesi Tip Fakültesi, Aile Hekimliği A.D, Sakarya \\ T: +905330946333 E-mail: : drgm54@gmail.com
}

Geliş Tarihi / Received : 19.08.2019 Kabul Tarihi / Accepted : 18.09.2019

Orcid :

Özlem Kirişci https://orcid.org/0000-0003-4784-8183

Gürkan Muratdağ1 https://orcid.org/0000-0002-9629-3973

( Sakarya Tip Dergisi / Sakarya Med J 2019, 9(4):585-591) DOI: 10.31832/smj.606475

\footnotetext{
Öz

Amaç Hastanemize başvuran akut gastroenteritli hastalarda rotavirüs ve enterik adenovirüs sıklı̆̆ını, yaş ve mevsimsel dağılımını belirlemeyi amaçladık.

Gereç ve 1 Nisan 2018-31 Mart 2019 tarihleri arasında hastanemize gastrointestinal şikayetler ile başvuran hastalardan, rotavirüs antijenini saptamak için 2758, adenovirüs antijenini Yöntemler saptamak için 2737 dışkı örneği retrospektif olarak incelenmiștir. Dışkı örneklerinde rotavirüs ve enterik adenovirüs antijenlerinin varlı̆̆ kalitatif immünokromatografik test (RDS adenovirüs ve rotavirüs (AV-RV) Kombo Test Kiti, Türkiye) ile araștırıldı.

Bulgular Arastırılan örneklerin 558'inde (\% 20.2) rotavirüs antijeni, 83'ünde (\% 3) adenovirüs antijeni, 8'inde (\% 0.3) rotavirüs ve adenovirüs antijenleri birlikte pozitif olarak saptanmıştır. Rotavirüs antijeni erkek hastaların \% 20.6'sında, kadınların \% 19.7'sinde pozitif olarak saptanmıs olup, cinsiyetler arasında istatistiksel olarak anlamlı farklılık bulunmamıștır ( $\mathrm{p}=0.545$ ). Rotavirüs antijeni pozitif bulunan olguların 502'si (\% 89.8) 0-5 yaş grubu hastalardan oluşurken, bu grup içinde antijen pozitifliği en çok 0-12 ay (\% 36.4) aralığı arasındaki çocuklarda saptanmıștır. Mevsim olarak en sık ilkbahar aylarında (\% 34.9) pozitiflik tespit edilmiștir. Yaș gruplarına ve mevsimlere göre rotavirüs antijeni saptanması arasında istatistiksel anlamlı ilișki saptanmıștır (sırayla $\mathrm{p}<0.001, \mathrm{p}<0.001$ ). Adenovirüs antijeni pozitifliği en çok 25-72 ay arasındaki çocuklarda (685 olgunun 28 'inde (\% 33.7)) görülmüsstür. Adenovirüs antijeni pozitifliği ile yaș grupları arasında istatistiksel anlamlı ilişki saptanmıștr(r( $\mathrm{p}=0,002)$. Adenovirüs antijeni pozitifliği ile cinsiyet ve mevsimsel dağılım arasında istatistiksel anlamlı ilişki saptanmamıștır(sırası ile $\mathrm{p}=0.115, \mathrm{p}=0.274$ ).

Sonuç İshalli olgular yașa ve mevsime göre değerlendirilmelidir. Akut gastroenteritli olgularda viral etkenlerin saptanmasında immünokromatografik yöntemle hızlı tanı testlerinin kullanılmasıyla gereksiz tetkik istemleri azalacak, erken tanı ve tedavi olanağı sağlanacak ve ampirik antibiyotik kullanılması önlenecektir.

Anahtar Akut Gastroenterit; Rotavirüs; Adenovirüs; İmmünokromatografi

Kelimeler

Abstract

Objective We aimed to determine the frequency, age and seasonal distribution of rotavirus and enteric adenovirus in patients with acute gastroenteriti.

Materials 2758 stool samples for rotavirus and 2737 for adenovirus were examined retrospectively to determine antigens between April 1, 2018 and March 31, 2019. Rotavirus and enteric adenovirus and Methods antigen in the stool specimens were investigated by qualitative immunochromatographic test (RDS adenovirus, and rotavirus (AV-RV) Combo Test Kit, Turkey).

Results Rotavirus antigen was positive in $558(20.2 \%)$, adenovirus antigen was positive in $83(3 \%)$ and rotavirus and adenovirus antigens were together positive in $8(0.3 \%)$ of the stool samples. Rotavirus antigen was positive in $20.6 \%$ of male patients and $19.7 \%$ of female patients and there was no statistically significant difference between the genders ( $p=0.545)$. $502(89.8 \%)$ of the patients with positive rotavirus antigen were in 0-5 age group, and in this age group, positivity was found mostly in children between 0-12 months (36.4\%). The positivity was mostly observed in the spring months (34.9\%). A statistically significant relationship was found between the positivity of rotavirus antigen and age groups and seasons $(p=0<001, p<0.001$, respectively). Adenovirus antigen positivity was found mostly in children between $25-72$ months ( 28 out of 685 cases (33.7\%)). There was a statistically significant relationship between adenovirus antigen positivity and age groups $(p=0.002)$. There was no statistically significant relationship between adenovirus antigen positivity and gender and seasonal distribution $(p=0.115, p=0.274$, respectively).

Conclusion Diarrhea cases should be evaluated according to age and season. Immunochromatographic methods for rapid detection of viral agents in acute gastroenteritis will reduce unnecessary examination requirements, provide early diagnosis and treatment, and prevent empirical antibiotic use.

Keywords Acute Gastroenteritis; Rotavirus; Adenovirus; Immunochromatographic
} 


\section{GIIRIŞ}

Akut gastroenterit (AGE), alt solunum yolu enfeksiyonlarından sonra çocuklarda yüksek morbidite ve mortalitenin ikinci en sık nedenidir. ${ }^{1}$ Beş yaşından küçük çocuklarda dünyada her yıl yaklaşık 1,4 milyar ishal vakası görülmekte olup bunların 1,29 milyarı evde bakım ile düzelirken 124 milyonu doktora başvurmakta, 9 milyonu hastaneye yatırılmakta ve yaklaşık 2,1 milyonu da dehidratasyon nedeni ile ölmektedir. ${ }^{2-5}$ Tüm dünyada 0-2 yaş grubunda en sık gastroenterit etkeni virüsler olup, bunların başında da ilk sırayı rotavirüs (RV) ve ikinci sıklıktada enterik adenovirüs (EAV) almaktadır. ${ }^{6}$ Gelişmiş ve gelişmekte olan ülkelerdeki çocuklarda ciddi gastroenteritlerin en önde gelen sebebi olan rotavirüs, her yıl 0-5 yaş arası çocuklardaki 2.1 milyon ölümün 440 bininden sorumludur. ${ }^{7}$ Rotavirüs ve enterik adenovirüs gastroenteritlerinin laboratuvar tanısında, taze dışkı örneklerinde antijen belirleme esasına dayanan immünokromatografik yöntemler kullanılmakta olup, ELISA(Enzim Linked Immun Assay) ile uygunluk göstermeleri, kısa sürede hızlı sonuç vermeleri, özel teknik, deneyim ve alet gerektirmeden çok sayıda hasta örneğiyle kolaylıkla çalışılabilmesi ve de özgüllük ve duyarlılıklarının (\%70-100) yüksek olması nedeniyle en çok kullanılan yöntemlerdir. ${ }^{8}$

Amerikan Gıda ve İlaç Dairesi (FDA) tarafından 2006 ve 2008 yıllarında onaylanan iki rotavirüs aşısı 100'den fazla ülkede ruhsat almıştır ve Ocak 2015 itibarı ile 75 ülkede ulusal bağışıklama programında yer almaktadır. ${ }^{9}$ Ülkemizde rotavirüs aşıları ücreti aileler ve/ veya özel sağlık sigortaları tarafından karşılanabilen ulusal aşı programında yer alan özel aşıları içeren çocukluk çağı genişletilmiş aşı takviminde 2 ., 4 . ve 6 . aylarda yapılmaktadir. ${ }^{10}$

Bölgemizde hastanemize başvuran akut gastroenteritlerin epidemiyolojisini belirlemek maksadıyla Necip Fazıl Şehir Hastanesi Kadın Doğum Hizmet Binası Mikrobiyoloji Laboratuvarına gönderilen, akut gastroenterit ön tanılı hastalardan alınan taze dışkı örneklerinden rotavirüs ve enterik adenovirüs oranının belirlenmesi, aylara göre da- ğ̊lımının incelenmesi ve çalışma sonuçlarının bu konuda önümüzdeki yıllarda yapılacak olan çalışmalara kaynak oluşturması amaçlanmıştır.

\section{GEREÇ ve YÖNTEM}

Kahramanmaraş Necip Fazıl Şehir Hastanesi Kadın Doğum ve Çocuk Hastalıkları Hastanesi’ne 1 Nisan 2018 - 31 Mart 2019 tarihleri arasında günde 3 veya daha fazla sulu dışkılama, karın ağrısı, kusma ve ateş gibi şikayetler ile başvurup akut gastroenterit tanısı alarak taze dışkı örneklerinde rotavirüs ve enterik adenovirüs antijen testi istenen hastalara ait kayıtlar retrospektif olarak incelenmiştir. Hastalar yaşlarına göre 0-12 ay, 13-24 ay, 25-72 ay, 6-16 yaş ve 16-18 yaş olmak üzere beş gruba ayrılmıştır. Bakteriyolojik veya parazitolojik inceleme yapılmaksızın, klinisyen hekimin şüpheli vakalardan rotavirüs ve adenovirüs antijen testi istemi doğrultusunda çalışılan dışkı örnekleri çalışmaya alınmıştır. Rektal sürüntü materyali kabul edilmemiştir. Taze dışkıda rotavirüs ve adenovirüs antijeni, ticari olarak temin edilen monoklonal anti-rotavirüs, anti-adenovirüs antikorlar ile kaplanmış nitroselüloz zarın tarayıcı olarak kullanıldığı immünokromatografik test (RDS adenovirüs ve rotavirüs (AV-RV) Kombo Test Kiti, Türkiye) ile üretici firmanın önerileri doğrultusunda araştırılmıştır. Bu test yöntemi, dışkıda bulunan rotavirüs ve/veya adenovirüs antijenlerinin antikor kaplı membrana bağlanıp 10-15 dakikalık inkübasyonu takiben test kartında antijen-antikor kompleksinin oluşumunu test bölgesinde(T1-T2) görünür bir pembe çizgi oluşturması prensibine dayanan hızlı, kalitatif bir yöntemdir. Her kasette bulunan internal kontrol bandının oluşup oluşmadığı testin geçerliliğini saptamak için kontrol edilmiştir. Monoklonal antikorlar tarafından yakalanan viral antijenlerin oluşturduğu bantların görülmesi pozitiflik olarak değerlendirilmiştir. Kontrol band 1 ile birlikte T1 alanında oluşan pembe çizgi adenovirüs pozitifliği, T2 alanında oluşan pembe çizgi rotavirüs pozitifliğini, T1 ve T2 alanında oluşan pembe çizgi ise adenovirüs ve rotavirüs pozitifliği olarak kaydedilmiştir. Elde edilen sonuçlar aylara, yaş ve cinsiyet farklılıklarına göre değerlendirilmiştir. Çalışmamız kesitsel tipte tanımla- 
yıcı bir çalışma olup Sakarya Üniversitesi Tıp Fakültesi Etik Kurulundan onam alınmıştır (Etik kurul onam sayı: 71522473/050.01.04/166, Tarih: 24.05.2019).

Veriler SPSS 24.0 (IBM SPSS Statistics 24 software (Armonk, NY: IBM Corp.) paket programılla analiz edilmiştir. Kategorik değișkenler sayı ve yüzde olarak ifade edilmiştir. Karşılaştırmalar için Ki-kare analizi kullanılmıştır. Tüm analizlerde $\mathrm{p}<0,05$ istatistiksel olarak anlamlı kabul edilmiştir.

\section{BULGULAR}

Çalışmaya dahil edilen rotavirüs antijeni bakılan 2758 hastanın 1168'inin (\% 42.3) kız, 1590'sinin (\% 57.7) erkek olduğu, yaş ortalamasının $3 \pm 4.35$ olduğu, adenovirüs antijeni bakılan 2738 hastanın 1155'inin (\% 42.2) kız, 1583'ünün (\% 57.8) erkek olduğu, yaş ortalamasının $3 \pm 4,35$ olduğu saptanmıştır. Araştırılan örneklerin 558'inde (\% 20.2) rotavirüs, 83’ünde (\% 3) adenovirüs antijeni tespit edilmiştir. Sekiz örnekte rotavirüs ve adenovirüs antijenleri birlikte (\% 0.3) pozitif olarak saptanmıştır. Rotavirüs antijeni erkek hastaların \% 20.6’unda, kadınların \% 19.7’ünde pozitif olarak saptanmış olup, cinsiyetler arasında istatistiksel olarak anlamlı farklılık bulunmamıştır ( $\mathrm{p}=0.545)$. Rotavirüs antijeni pozitif bulunan olguların 502'si (\% 89.8) 0-5 yaş grubu hastalardan oluşurken, antijen pozitifliği en çok yaş aralığı olarak 0-12 ay (\% 36.4) arasında bulunan çocuklarda saptanmıştır. Rotavirüs antijen pozitifliği en sık ilkbahar aylarında (\% 34.9) tespit edilmiştir. Yaş gruplarına ve mevsimlere göre rotavirüs antijeni saptanması arasında istatistiksel anlamlı ilişki saptanmıştır ( $\mathrm{p}=0.000, \mathrm{p}=0.000$; Tablo 1). Tablo 1 de rotavirüs antijen pozitifliği saptanan hastaların cinsiyet, yaş ve mevsimlere göre dağılımı görülmektedir.

\begin{tabular}{|c|c|c|c|}
\hline Özellik & pozitif $n(\%)$ & Negatif n(\%) & p değeri \\
\hline \multicolumn{4}{|l|}{ Cinsiyet } \\
\hline erkek & $328(\% 58.8)$ & $1262(\% 57.4)$ & \multirow{2}{*}{0.545} \\
\hline kadın & $230(\% 41.2)$ & $938(\% 42.6)$ & \\
\hline \multicolumn{4}{|l|}{ Yaş grupları } \\
\hline $0-12$ ay & $203(\% 36.4)$ & $648(\% 29.5)$ & \multirow[t]{5}{*}{$0.000^{*}$} \\
\hline 13-24 ay & $188(\% 33.7)$ & $434(\% 19.7)$ & \\
\hline $25-72$ ay & $111(\% 19.9)$ & $575(\% 26.1)$ & \\
\hline 6-16 yaş & $54(\% 9.7)$ & $522(\% 23.7)$ & \\
\hline 16-18 yaş & $2(\% 4)$ & $21(\% 1)$ & \\
\hline \multicolumn{4}{|l|}{ Mevsimler } \\
\hline İlkbahar & $195(\% 34.9)$ & $536(\% 24.4)$ & \multirow[t]{5}{*}{$0.000^{*}$} \\
\hline Yaz & $60(\% 10.8)$ & $658(\% 29.9)$ & \\
\hline Sonbahar & $148(\% 26.5)$ & $611(\% 27.8)$ & \\
\hline Kiş & $155(\% 27.8)$ & $395(\% 18)$ & \\
\hline Toplam & $558(\% 20.2)$ & $2200(\% 79.8)$ & \\
\hline
\end{tabular}


Adenovirüs antijeni saptanması ile cinsiyet ve mevsimsel dağılım arasında istatistiksel anlamlı ilişki saptanmamıştır (sırası ile $\mathrm{p}=0.115, \mathrm{p}=0.274$; Tablo 2). Adenovirüs antijen pozitifliği en çok 25-72 ay aralığında görülmüştür. [685 olgunun 28 'inde (\% 33.7)]. 6 yaş üstündeki 590 olgunun ise 6’sında (\%7.2) adenovirüs pozitifliği saptanmıştır. Adenovirüs antijeni saptanması ile yaş grupları arasında istatistiksel anlamlı ilişki saptanmıştır(p=0,002). Tablo 2 de adenovirüs antijen pozitifliği saptanan hastaların cinsiyet, yaş ve mevsimlere göre dağılımı görülmektedir.

\begin{tabular}{|c|c|c|c|}
\hline Özellik & pozitif $\mathbf{n}(\%)$ & Negatif n(\%) & p değeri \\
\hline \multicolumn{4}{|l|}{ Cinsiyet } \\
\hline erkek & $42(\% 50.6)$ & 1113(\%41.9) & \multirow{2}{*}{0.115} \\
\hline kadın & $41(\% 49.4)$ & $1542(\% 58.1)$ & \\
\hline \multicolumn{4}{|l|}{ Yaş grupları } \\
\hline $0-12$ ay & $22(\% 26.5)$ & $822(\% 31)$ & \multirow[t]{5}{*}{ “0.002 } \\
\hline 13-24 ay & $27(\% 32.5)$ & $592(\% 22.3)$ & \\
\hline 25-72 ay & $28(\% 33.7)$ & $657(\% 24.7)$ & \\
\hline 6-16 yaş & $6(\% 7.2)$ & $567(\% 21.4)$ & \\
\hline $16-18$ yaş & $0(\% 0.0)$ & $17(\% 6)$ & \\
\hline \multicolumn{4}{|l|}{ Mevsimler } \\
\hline İlkbahar & $18(\% 21.7)$ & 706(\%26.6) & \multirow{5}{*}{0.274} \\
\hline Yaz & $17(\% 20.5)$ & 691(\%26) & \\
\hline Sonbahar & $26(\% 31.3)$ & 731(\%27.5) & \\
\hline Kış & $22(\% 26.5)$ & $527(\% 19.8)$ & \\
\hline Toplam & $83(\% 3)$ & $2655(\% 97)$ & \\
\hline
\end{tabular}

Rotavirüs antijeni pozitifliği ile aylar arasında istatistiksel $\quad \operatorname{tır}(\mathrm{p}>0.05)$. Rota ve adenovirüs antijen saptanma duruanlamlı ilişki saptanmışken $(\mathrm{p}=0.000)$, adenovirüs anti- munun aylara göre dağılımı Tablo 3’te verilmiştir. jeni ile aylar arasında istatistiksel bir ilişki saptanmamış-

\begin{tabular}{|c|c|c|c|c|c|c|}
\hline \multicolumn{4}{|c|}{ Rotavirüs } & \multicolumn{3}{|c|}{ Adenovirüs } \\
\hline Aylar & Pozitif n \% & Negatif n \% & p değeri & Pozitif n \% & Negatif n \% & p değeri \\
\hline Nisan 2018 & $55(\% 9.9)$ & $201(\% 9.1)$ & \multirow[t]{13}{*}{${ }^{*} \mathrm{p}=\mathbf{0 . 0 0 0}$} & $7(\% 8.4)$ & $247(9.3)$ & \multirow[t]{13}{*}{$p=0.328$} \\
\hline Mayıs 2018 & $39(\% 7.0)$ & $206(\% 9.4)$ & & $6(\% 7.2)$ & $236(\% 8.9)$ & \\
\hline Haziran 2018 & $28(\% 5.0)$ & $229(\% 10.4)$ & & $4(\% 4.8)$ & $247(\% 9.3)$ & \\
\hline Temmuz 2018 & $26(\% 4.7)$ & $283(\% 12.9)$ & & $11(\% 13.3)$ & $295(\% 11.1)$ & \\
\hline Ağustos 2018 & $6(\% 1.1)$ & $146(\% 6.6)$ & & $2(\% 2.4)$ & $149(\% 5.6)$ & \\
\hline Eylül 2018 & $20(\% 3.6)$ & $191(\% 8.7)$ & & $4(\% 4.8)$ & $206(\% 7.8)$ & \\
\hline Ekim 2018 & $51(\% 9.1)$ & $207(\% 9.4)$ & & $10(\% 12.0)$ & $247(\% 9.3)$ & \\
\hline Kasim 2018 & $77(\% 13.8)$ & $213(\% 9.7)$ & & $12(\% 14.5)$ & $278(\% 10.5)$ & \\
\hline Aralık 2018 & $33(\% 5.9)$ & $135(\% 6.1)$ & & $5(\% 6.0)$ & $164(\% 6.2)$ & \\
\hline Ocak 2019 & $53(\% 9.5)$ & $113(\% 5.1)$ & & $10(\% 12.0)$ & $154(\% 5.8)$ & \\
\hline Şubat 2019 & $69(\% 12.4)$ & $147(\% 6.7)$ & & $7(\% 8.4)$ & $209(\% 9.9)$ & \\
\hline Mart 2019 & $101(\% 18.1)$ & $129(\% 5.9)$ & & $5(\% 6.0)$ & $223(\% 8.4)$ & \\
\hline Toplam & $558(\% 20.2)$ & $2200(\% 79.8)$ & & $83(\% 3)$ & $2655(\% 97)$ & \\
\hline
\end{tabular}




\section{TARTIŞMA}

Akut gastroenterit (AGE) etiyolojisinde vakaların \% 20'sinden bakteriyel ajanlar sorumlu tutulurken, geri kalan vakaların büyük kısmında (\%30-70) virüslerin etken olduğu tahmin edilmektedir. Bakteri ve parazitlere bağlı gastroenteritlerin insidansında korunma önlemlerinin arttırılması ile belirgin bir düşme sağlanmıştır. Ancak virüslere bağlı gastroenteritlerin sıklı̆̆ının giderek arttığı gözlenmektedir. ${ }^{11,12,15}$ Viral AGE’ler içerisinde en sık karşılaşılan ajan özellikle 5 yaş altındaki çocuklarda rotavirüs, diğer bir sık karşılaşılan ajan ise enterik adenovirüslerdir. Akut gastroenteritli olgularda lateks aglütinasyon ve ELISA gibi hızlı tanı testleri ile tanı konularak tedavi etme yoluna gidilmektedir. Tedavinin temelinde ise esasen hidrasyonun sağlanması, yüksek ateş ve kusmaya yönelik semptomatik tedavinin uygulanması yer almaktadır. ${ }^{13}$
Yurt dışında yapılan çalışmalarda, rotavirüsün viral gastroenterit vakalarının \%11-71'inden sorumlu olduğu bildirilirken, enterik adenovirüs için \% 2-22.2, rotavirüs-enterik adenovirüs birlikte pozitifliği için \%1.3-6 olarak belirtilmiştir. ${ }^{14-21}$

Ülkemizde yapılan farklı çalışmalarda rotavirüs sıklığı \% 9.8-39.8 oranı arasında değişiriken, enterik adenovirüs sıklığ $\%$ 5-15 oranında bildirilmiştir. ${ }^{11,12,15,22,23}$ Çalışmamızda, hastanemize akut gastroenterit şikayetiyle başvuran hastalarda rotavirüs sıklığını \% 20,2, enterik adenovirüs sıklığını \% 3.0 olarak tespit edilmiștir. Vakalarımızın \% 0.3’ünde rotavirüs-enterik adenovirüs birlikte pozitif olarak tespit edilmiştir. Çalışmamızda bulunan rotavirüs ve adenovirüs sıkllğı literatürle uyumlu olduğu görülmüsstür. Tablo 4’te ülkemizde rotavirüs ve adenovirüs sıklı̆̆ını araştıran çalışmalar görülmektedir.

\begin{tabular}{|c|c|c|c|c|c|c|}
\hline Araştırmacı & Merkez & Rotavirüs\% & Adenovirüs\% & Birliktelik\% & Tarih & Yöntem \\
\hline Akan ve ark. ${ }^{24}$ & İstanbul & 18.7 & 8.9 & 4.4 & 2009 & İK \\
\hline Albayrak ve ark. ${ }^{25}$ & Ankara & 16.0 & 4.0 & - & 2011 & Real-time PCR \\
\hline Gültepe ve ark. ${ }^{26}$ & Van & 13 & 8.5 & 4.5 & 2013 & İK \\
\hline Atalay ve ark. ${ }^{27}$ & Kayseri & 25.2 & - & - & 2013 & İK \\
\hline Özdemir ve ark. ${ }^{28}$ & Konya & 17.3 & 2.6 & 0.0 & 2013 & İK \\
\hline Türk Dağı ve ark. ${ }^{29}$ & Konya & 9.8 & 1.3 & 1.0 & 2014 & İK \\
\hline Doğan ve ark. ${ }^{30}$ & Gaziantep & 12.1 & 4.3 & 1.8 & 2014 & İK \\
\hline Süzük ve ark. ${ }^{31}$ & Kırıkkale & 16.6 & - & - & 2015 & İK \\
\hline Çömçe ve ark ${ }^{.32}$ & İstanbul & 22.4 & 3.1 & - & 2017 & ELISA \\
\hline Agah Terzi ve ark. ${ }^{33}$ & Sakarya & 14.1 & 7.6 & - & 2018 & İK \\
\hline Topal ve ark. ${ }^{34}$ & Erzincan & 10.4 & - & - & 2019 & İK \\
\hline Şimdiki çalışma & Kahramanmaraş & 20.2 & 3.0 & 0.3 & 2019 & İK \\
\hline
\end{tabular}

Yapılan çalışmalarda, viral gastroenterit sıklığında cinsiyet açısından bir fark olmadığı bildirilmiştir. ${ }^{14}$ Ülkemizde rotavirüs pozitifliği ile cinsiyet farkı olmadığını gösteren çalışmalar mevcuttur. ${ }^{27,29}$ Akıncı ve ark. ise rotavirüsün kızlarda adenovirüsün de erkeklerde anlamlı olarak daha sık görüldüğünü bildirirken Türk Dağı ve ark. adenovirüsün kızlarda erkeklere göre anlamlı olarak yüksek sıklıkta görüldüğünü bildirmiştir. ${ }^{15,29}$ Çalışmamızda, literatüre pa- ralel olarak hem rotavirüs hem de adenovirüs için viral antijen pozitifliği yönünden cinsiyetler arasında anlamlı bir ilişki görülmemiştir. (sırayla $\mathrm{p}=0.545, \mathrm{p}=0,115$ ).

Rotavirüs enfeksiyonları tropikal bölgelerde tüm yıl boyunca görülmekle birlikte, ülkemizde ve ılıman iklime sahip ülkelerde özellikle kış ayları ve ilkbahar başında görülmektedir. Adenovirüs ise herhangi bir mevsimsel özellik 
göstermemekte ve yılın her ayında AGE'ye neden olabilmektedir. ${ }^{12,15,17,22}$ Literatüre bakıldığında rotavirüs enfeksiyonlarının sonbahar ve kış aylarında arttığını bildiren çalışmalar vardır. ${ }^{35,36}$ Ancak son yıllarda yapılan çalışmalarda özellikle rotavirüs aşılarının kullanıma girmesinden sonra epidemiyolojisinde değişikliklerin görüldüğü bildirilmektedir. $^{36,37}$ Çalışmamızda rotavirüs sıklığı ilkbahar mevsiminde diğer mevsimlere göre $\% 34,9$ ile en yüksek oranda tespit edilmiş olup, rotavirüs pozitifliği ile mevsimsel dağılım arasında istatistiksel anlamlı bir fark bulunmuştur $(\mathrm{p}=0,000)$, literatüre paralel şekilde adenovirüs pozitifliği ile mevsimsel dağılım arasında istatistiksel bir fark tespit edilememiştir ( $\mathrm{p}=0,274)$.

Rotavirüs enfeksiyonları en sık 2 yaş altı çocuklarda görülür. Bu bulguyu destekleyecek pek çok çalışma bulunmaktadır. ${ }^{3,8,14,16,38}$ Ancak adenovirüs her yaş grubunda hastalık etkeni olabilmektedir. Hem rotavirüs hem de enterik adenovirüs gastroenteritlerinin \%50'sinden fazlasının 12 ay altı yaş grubunda görüldüğü bildirilen çalışmaların yanı sıra her iki virüs enfeksiyonunda yaş dağılımı açısından bir farklılık saptanmayan çalışmalar da mevcuttur. ${ }^{39,40}$ Çalışmamızda da, rotavirüs pozitifliği literatür ile uyumlu olarak 0-12 ay yaş grubunda istatistiksel olarak anlam1 düzeyde daha yüksek olduğu saptanmıştır $(\mathrm{p}=0.000)$. Rotavirüs enfeksiyonu kısmi bağışıklık bırakır ve sonraki her enfeksiyonla bağışıklık artar. İki yaş üzeri çocuklarda hastalığın sıklığı ve şiddeti azalır. İlk enfeksiyonun 2 yaşından önce geçirilmesi, dehidratasyon ve malnutrisyonla seyretmesi mortaliteyi artırmaktadır. Bu nedenle doğal bağışıklık yerine hastalığın ilk karşılaşma öncesi aşılama ile önlenmesi daha akılcı görünmektedir. ${ }^{19,39}$ Çalışmamızda adenovirüs pozitifliği ile yaş grupları arasında ise 25-72 ay yaş grubunda istatistiksel olarak anlamlı düzeyde daha yüksek olduğu saptanmıştır $(\mathrm{p}<0.002)$.

\section{SONUÇ}

$\mathrm{Bu}$ çalışma ile hastanemizin hizmet verdiği bölgede rotavirüslerin özellikle ilkbahar aylarında gelişen enfeksiyöz gastroenteritlerde önemli etkenler olduğu, rotavirüs enfeksiyon sıklığının, adenovirüs enfeksiyonundan daha fazla olduğu görülmüştür. Tanıda immünokromotografik testler gibi hızlı tanı testlerinin kullanılmasının doğru tedavinin başlanmasında ve de gereksiz antibiyotik kullanımının önüne geçilmesinde faydalı olacağı, erken müdahale ile hem dehidratasyon-malnutrisyon gelişimi hem de önemli komplikasyonların gelişmesinin engelleneceği kanaatindeyiz. Viral gastroeneterit etkeni rotavirüs ve adenovirüs etkenlerinin cinsiyete, yaşa ve mevsimlere göre dağılımını içeren çalışmamızın ilimiz epidemiyolojik verilerine katkı sağlayacağı ve yapılacak olan aşılama programları için veri kaynağı oluşturması açısından faydalı olacağı düşünülmektedir. 
Sakarya Tip Dergisi 2019;9(4):585-591

KİRIŞCİ ve Ark., Rotavirüs ve Enterik Adenovirüs Enfeksiyonu Sıklı̆̆ı

\section{Kaynaklar}

1. Kosek M, Bern C, Guerrant RL. The global burden of diarrhoeal disease, as estimated from studies published between 1992 and 2000. Bull World Health Organization 2003; 81:19704.

2. Gül M, Garipardıç M, Çıragil P, Aral M, Karabiber H, Güler İ. 0-5 yaş arası gastroenteritli çocuklarda Rotavirüs ve Adenovirüs Tip 40/41 araşttrılması. Ankem Derg 2005;19: 64-67.

3. Meqdam MM, Thwiny IR. Prevalence of group a rotavirus, enteric adenovirus, norovirus and astrovirus infections among children with acute gastroenteritis in Al-Qassim, Saudi Arabia. Pak J Med Sci 2007;23:551-5.

4. Parashar UD, Hummelman EG, Bresee JS, Miller MA, Glass RI. Global illness and deaths caused by rotavirus disease in children. Emerging Infectious Diseases 2003;9: 565-72.

5. Elliott EJ. Acute gastroenteritis in children. BMJ 2007;334:35-40.

6. Bulut Y, I̦șeri L, Ağel E, Durmaz B. Akut gastroenterit ön tanil çocuklarda rotavirüs pozitifliğgi. İnönü Üniv Tip Bült 2003;10(3):143-5.

7. Parashar UD, Burton A, Lanata C, Boschi-Pinto C, Shibuya K, Steele D et al. Global mortality associated with rotavirus disease among children in 2004, J Infect Dis 2009;200:S9-15.

8. Tekin A. The frequency of rotavirus and enteric adenovirus in children with acute gastroenteritis in Mardin. J Clin Exp Invest 2010; 1(1): 41-5.

9. Kocabaș E, Dayar GT. Rotavirus așları. J Pediatr Inf 2015; 9: 166-74)

10. Gülcü S, Arslan S. Çocuklarda aşı uygulamalarl: Güncel bir gözden geçirme. Düzce Üniversitesi Sağllk Bilimleri Enstitüsü Dergisi 2018; 8(1): 34-43

11. Palanduz A. Gastrointestinal enfeksiyon etkenleri ve neden oldukları klinik tablolar. J Pediatr Inf 2009; 3:116-8.

12. Biçer S, Șahin GT, Koncay B, Yavuzcan D, Gemici H, Engerek $N$ ve ark. Çocuk acil servisinde saptanan rotavirüs gastroenteriti olgularının sıklğı. J Pediatr Inf 2008; 3:96-9.

13. Ciccarelli S, Stolfi I, Caramia G. Management strategies in the treatment of neonatal and pediatric gastroenteritis. Infection and Drug Resistance. 2013;6:133-161.

14. Yousefi Rad A, Gözalan A. Detection of Rotavirus and Enteric Adenovirus Antigens in Outpatients with Gastroenteritis. Turkiye Klinikleri J Med Sci 2010;30:174-9

15. Akıncı N, Ercan TE, Yalman N, Eren A, Severge B, Ercan G. Akut gastroenteritli çocuklarda Adenovirüs ve Rotavirüs. J Pediatr Inf 2007;1:98-101.

16. Karsligil T, Kıllı̧ İH, Balcı İ. 0-6 Yaş Çocuklarda Rotavirüs Gastroenteritleri ve Bunun Laktoz İntoleransı Üzerine Etkisi. Türk Mikrobiyol Cem Derg 2003;33:137-42.

17. Altındiş M, Beștepe G, Çeri A, Yavru S, Kalaycı R. Akut ishal yakınmalı çocuklarda Rotavirüs ve Enterik Adenovirüs siklğ̆l. S.D.Ü. Tip Fak. Derg. 2008;15(2):17-20.

18. İnci A, Kurtoğlu MG, Baysal B. Bir eğitim ve araștırma hastanesinde Rotavirüs Gastroenteriti prevalansinin arașttrllmast. Turk J Infection 2009; 23:79-82.

19. Șimşek Y, Bostancı İ, Bozdayı G, Öner N, Kamruddin A, Rota S ve ark. 0-5 Yaş çocuklarda akut gastroenteritte Rotavirüs stklğg ve serotip özellikleri. Turkiye Klin J Pediatr 2007; 16:165-70.

20. Altındiș M, Yavru S, Șimşek A, Özkul A, Çeri A, Koç H. Rotavirus infection in children with acute diarrhea as detected by latex agglutination, ELISA and polyacrylamide gel electrophoresis. Indian Pediatrics 2004;41:590-4.

21. Nazik H, İlktaç M, Öngen B. Çocukluk yaş grubu gastroenteritlerinde Rotavirüs sıklŭgının araștırılması. Ankem Derg 2006; 20:233-5.

22. Biçer S, Bezen D, Sezer S, Yavuzcan D, Akpınar Tekgündüz S, Ulucaklı Ö ve ark. Acil çocuk servisindeki akut gastroenterit olgularında Rotavirüs ve Adenovirüs enfeksiyonları. Ankem Derg 2006;20(4):206-9
23. Kurugöl Z, Geylani S, Karaca Y, Umay F, Erensoy S, Vardar F et al. Rotavirus gastroenteritis among children under five years of age in Izmir, Turkey. Turk J Pediatr 2003;45:290-4. 24. Akan H, İzbrak G, Gürol Y, Sarıkaya S, Gündüz TS, Yllmaz G ve ark. Rotavirus and adenovirus frequency among patients with acute gastroenteritis and their relationship to clinical parameters: a retrospective study in Turkey. Asia Pacific Family Medicine 2009; 8:8.

25. Albayrak N, Yağcı Çağlayık D, Altaş AB, Korukluoğlu G, Ertek M. Refik Saydam Hıfzıssthha Merkezi Bașkanlığı, Viroloji Referans ve Araștırma Laboratuvarı, 2009 yılı akut viral gastroenterit verilerinin değerlendirilmesi. Turk Hij Den Biyol Derg 2011; 68(1):9-15. http://dx.doi.org/10.5505/TurkHijyen.2011.64326

26. Gültepe B, Güdücüoğlu H, Çıkman A, Parlak M, Berktaș M. Van yöresinde gözlenen gastroenteritlerde rotavirus ve adenovirus sıklğı. Sakarya MJ 2013; 3(3):131-4.

27. Atalay MA, Kandemir İ, Gökahmetoğlu S. Üçüncü basamak bir hastanedeki gastroenteritli çocuklarda rotavirüs enfeksiyonu sıkliğı. Dicle Tip Derg 2013; 40(2):212-5. http://dx.doi. org/10.5798/diclemedj.0921.2013.02.0256

28. Özdemir M, Demircili ME, Feyzioğlu B, Yavru S, Baysal B. İshali hastalarda akut viral gastroenterit etkenlerinin araștırlması. Selçuk Tip Derg 2013; 29(3): 127-30.

29. Türk Dağı H, Findık D. Akut gastroenteritli hastalarda rotavirüs ve adenovirüs antijenlerinin araștrrlmast. Journal of Clinical and Experimental Investigations 2014; 5 (2): 256-260.

30. Doğan Y, Ekşi F, Karsligil T, Bayram A. Akut Gastroenteritli Hastalarda Rotavirüs ve Adenovirüs Varliğının Arașttrılması. Türk Mikrobiyol Cem Derg 2014 44(1):18-22.

31. Süzük S, Avcıküçük H, Kavak M. Kırıkkale Yüksek İhtisas Hastanesỉne bașvuran akut gastroenteritli çocuklarda rotavirüs enfeksiyonunun sıklğı. Turk Hij Den Biyol Derg 2015; 72(1):11-16

32. Çömçe M, Kafadar D, Erol M, Yiğgit Ö. Akut Gastroenteritle Acile Başvuran Pediatrik Popülasyonda Rotavirüs ve Adenovirüs Enfeksiyonlarnnin Retrospektif Analizi. J Pediatr Inf 2017; 11(4): 153-160

33. Agah Terzi H, Aydemir Ö. Akut Gastroenteritli Hastalarda Rotavirüs ve Adenovirüs Siklğgnın Araștırılmasl; Sakarya. Sakarya Med J 2018, 8(4):746-752.

34. Topal İ, Çıkman A, Arslan YK, Sürücü Kara İ, Aydın Peker N, Karakeçili F. Akut Gastroenteritli Çocuklarda Rotavirüs Siklı̆gı. Firat Tip Dergisi/Firat Med J 2019; 24 (1): 14-17

35. Yüksel P, Çelik DG, Güngördü Z, Ziver T, İzmirli S, Yakar H ve ark. Çocukluk yaş grubu gastroenteritlerinde rotavirus antijen pozitiflĭginin değerlendirilmesi. Klimik Derg 2011; 24(1): 48-51.

36. Custodio H, Masnita-Iusan C, Wludyka P, Rathore MH. Change in rotavirus epidemiology in northeast Florida after the introduction of rotavirus vaccine. Pediatr Infect Dis J 2010; 29: 766-7.

37. Tate JE, Panozzo CA, Payne DC, Patel MM, Cortese MM, Fowlkes AL et al. Decline and change in seasonality of US rotavirus activity after the introduction of rotavirus vaccine. Pediatrics 2009; 124: 465-71.

38. Kurugöl Z. Rotavirüs Așlları. Turk Arch Ped 2007;42 Suppl:36-42.

39. Bates PR, Bailey AS, Wood DJ, Morris DJ, Jouriel JM. Comparative epidemiology of rotavirus, subgenus $F$ (types 40 and 41) adenovirus, and astrovirus gastroenteritis in children. J Med Virol 1993;39(3):224-8.

40. K H Kim, J M Yang, S I Joo, Y G Cho, R I Glass, Y J Cho. Importance of rotavirus and adenovirus types 40-41 in acute gastroenteritis in Korean children. J Clin Microbiol 1990;28:227984. 